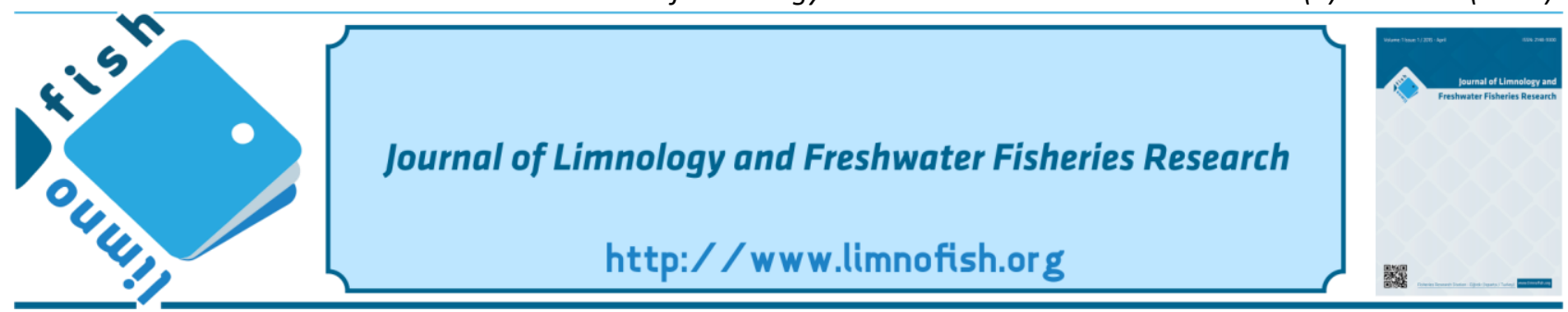

\title{
Mikroalgal Üretimlerde Kinetik Modelleme
}

\author{
Bahar ASLANBAY GÜLER ${ }^{1 *}$, Esra IMAMOĞLU ${ }^{1}$ iD \\ ${ }^{1}$ Ege Üniversitesi, Mühendislik Fakültesi, Biyomühendislik Bölümü, İzmir, Türkiye
}

Tek hücreli, basit organizmalar olan mikroalgler, sahip oldukları karakteristik özellikleri sayesinde gıda, çevre teknolojileri, enerji, kozmetik, ilaç, akuakültür gibi çeşitli endüstrilerde yaygın olarak kullanılmaktadır. Mikroalglere ve uygulama alanlarına olan ilgi her geçen gün artış gösterse de endüstriyel çaptaki üretimlerde çeşitli sorunlarla karşı karşıya kalınabilmektedir. Organizmaların büyüme kinetiği ve hedef ürün eldesi proseslerdeki temel aşamalardan olup, bu aşamalarda meydana gelebilecek herhangi bir problem, sistemin tamamını olumsuz etkilemektedir. Bu problemleri önlemek için izlenebilecek yollardan biri, hücrelerin büyümesini ve ürün miktarını etkileyen parametrelerin kullanımıyla kinetik modeller geliştirilmesidir. Matematiksel modeller ile üretim sırasında elde edilen sonuçların sayısal olarak ifadesi sağlanmakta ve böylece ölçek büyütmede ve benzer proseslerde kullanılabilecek güvenilir veriler elde edilmektedir. Bu makalede, mikroalg hücrelerinin büyümesi ve ürün üretimine dair geliştirilen kinetik modeller substrat, ışık ve sıcaklık parametreleri açısından değerlendirilerek literatürde kullanılan modeller özetlenmiştir.
\end{abstract}

MAKALE BILGISI

$\begin{array}{ll}\text { DERLEME } & \\ \text { Geliş } & : 31.08 .2020 \\ \text { Düzeltme } & : 30.12 .2020 \\ \text { Kabul } & : 09.01 .2021 \\ \text { Yayım } & : 26.08 .2021\end{array}$

DOI:10.17216/LimnoFish.787055

\section{* SORUMLU YAZAR}

esraimamoglu@yahoo.com

Phone : +902323115820

Fax : +90 2323115880

Anahtar kelimeler: Kinetik modelleme, mikroalg, 1şık yoğunluğu, substrat, sicaklık

\section{Kinetic Modelling of Microalgae Productions}

Abstract: Being simple organisms, unicellular microalgae are commonly used in several industrial applications such as food, environmental technologies, energy, cosmetic, pharmaceutical and aquaculture due to their specific features. Although the interest in microalgae and their application areas are increasing day by day, various problems may be encountered for their industrial scale production. Varieties of problems may be faced in their industrial scale production despite the interest on microalgae and their application areas are increasing day by day, Growth kinetics of organisms and target product formations are the basic stages in the processes when any problem that may occur during these stages affects the entire system negatively. One of the ways to prevent these problems is to develop kinetic models by means of using parameters that affect the growth of cells and the amount of product. Numerical expression of the results gained during the tproduction is provided with mathematical models, and thus, reliable data that can be used in scaling up and similar processes are obtained. In this article, the models used in the literature are summarized by evaluating the kinetic models developed for the growth of microalgae cells and product production in terms of substrate, light and temperature parameters.

Keywords: Kinetic modelling, microalgae, light intensity, substrate, temperature

Alıntılama

Aslanbay Güler B, İmamoğlu E. 2021. Mikroalgal Üretimlerde Kinetik Modelleme. LimnoFish. 7(2): 176-183. doi: 10.17216/LimnoFish.787055

\section{Giriş}

Biyolojik proseslerde hücrelerin büyüme karakteristikleri, ürün üretimi, substrat tüketimi gibi metabolik fonksiyonlar, üretime etki eden çeşitli parametrelerin değerlendirilmesiyle optimize edilmektedir. Uygun koşullarda gerçekleştirilen üretimler hem mevcut prosesin başarısını göstermekte hem de benzer proseslere model üretimler olarak kullanılabilmektedir. Üretim sırasında elde edilen sonuçların sözel ifadesi yerine sayısal olarak belirtilmesi sistemlerin verimliliğini tanımlamada daha gerçekçi sonuçlar ortaya çıkarmaktadır. Ayrıca benzer prosesler ya da ölçek büyütme işlemleri için gerekli verilerin kolay elde edilebilirliğini sağlamaktadır. Bu noktada hücrelerin davranışlarının matematiksel olarak ortaya konduğu kinetik modeller karşımıza çıkmaktadır.

Kinetik modelleme biyolojik bir prosesin nicel olarak ifadesidir. Matematiksel modeller prosesin kontrolüne yardımcı olurken, maliyeti düşürüp, ürün 
kalitesini arttırmaktadır. Laboratuvar ölçeğinden ticari ölçeğe geçişte yaşanan en büyük sorunlardan biri, büyük ölçekteki optimum koşulların öngörülememesidir. Çevresel parametrelerin her birinin ayrı ayrı denendiği optimizasyon çalışmaları ise özellikle maliyet açısından büyük kayıplara yol açmakta ve gereksiz zaman almaktadır. Her parametrenin büyük ölçekte denenmesi yerine küçük ölçekte yapılan üretim sonuçlarından matematiksel modellerin oluşturulması ve bunların yeni üretimlere entegrasyonu çok daha avantajlı bir yöntemdir (Koutinas vd. 2012). Kinetik modellerde hücre davranışları zamana göre irdelenerek hücre büyüme hızı, ürün oluşumu, substrat tüketimi gibi mekanizmalar matematiksel olarak belirlenebilmektedir. Hücre davranışlarını etkileyen parametrelerin çok sayıda olduğu göz önüne alındığında çeşitli araştırmalar sonucunda tüm parametrelerin değerlendirildiği farklı modeller geliştirilmiş ve proseslere göre modifikasyonları yapılmıştır. Geliştirilen modeller temelde süreç ve sonuç odaklı olmak üzere iki ana gruba ayrılmaktadır. "Açıklayıcı" modeller biyolojik süreçteki mekanizmaların nicel olarak ifadesine dayanır. Metabolik yolaklar, ara aşamalar ve son ürüne giderken geçilen aşamaların matematiksel modellemesi yapılmaktadır. Bu modeller son derece karmaşık olmasından dolayı üzerinde modifikasyonlarla sadeleștirilmeye çalıșılmaktadır. "Betimleyici" modeller ise sonuca odaklıdır. Bu modeller üretimin performansını öngörme yönünde geliştirilmiştir. Çoğu prosesin modellemesinde kolay ve amaca yönelik olmasından dolayı bu modeller kullanılmaktadır (James ve Boriah 2010; Lee vd. 2015; Huesemann vd. 2016).

Bu makalede, mikroalg hücrelerinin büyümesi ve ürün üretimine dair geliştirilen kinetik modeller substrat, 1 ş1k ve sicaklık parametreleri açısından değerlendirilerek literatürde kullanılan modeller özetlenmiştir.

\section{Mikroalgal Büyüme Hızının Kinetik Modellemesi}

Mikroalgal biyokütle üretiminde geliştirilen modeller 1şık yoğunluğu, sıcaklık, pH, çözünmüş oksijen ile karbonidoksit miktarı ve gerekli besinlerin konsantrasyonu gibi parametreleri içerdiğinden karmaşık modellerdir. Bu parametrelerin ayrı ayrı incelendiği modeller olduğu gibi birbirleriyle etkileşimlerini de göz önünde bulunduran çoklu faktör içeren modeller de kullanılmaktadır. Her ne kadar farklı model çeşitleri söz konusu olsa da temelde üretim süresince hücre davranışlarının iyi bir şekilde gözlemlenmesi gerekmektedir. Genel olarak mikroalgal üretimlerde hücre büyümesi 5 evreden oluşmaktadır (Şekil 1).

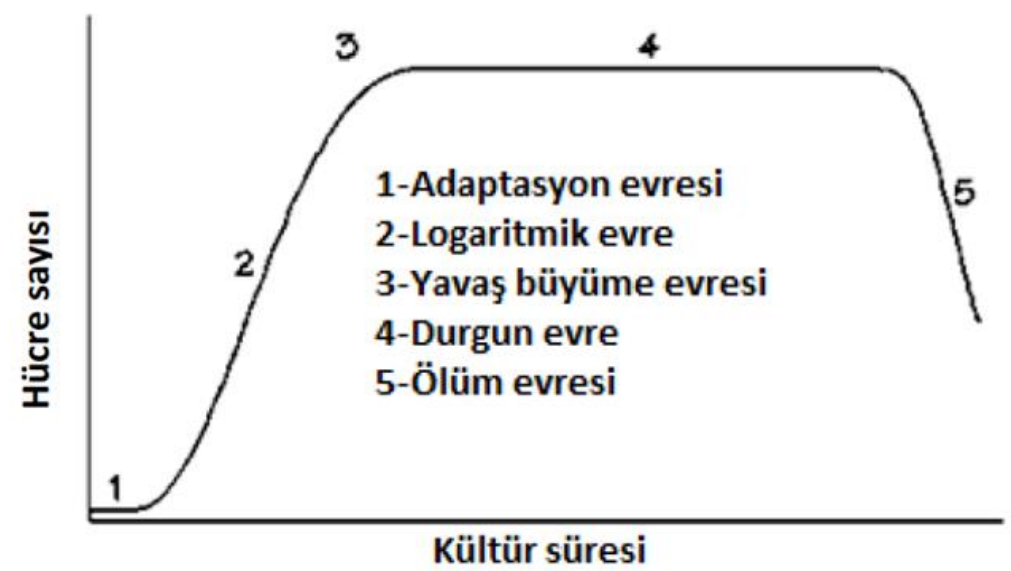

Şekil 1. Mikroalg kültürlerinde hücrelerin büyüme profili

Figure 1. Growth profile of cells in microalgae cultures

İlk aşama hücrelerin ortama ve koşullara uyum sağladığı "adaptasyon" evresidir. Bu aşamada hücre sayısında artış yoktur. Aksine adapte olamayan hücreler elimine olabilir. Optimum koşullar mevcut olduğunda 2-3 gün adaptasyon için yeterli süre olarak düşünülmektedir. Ardından ikinci evre hücre sayısında yüksek artışın görüldüğü "logaritmik" evredir. Koşullara adapte olan hücreler yüksek büyüme hızı göstererek yoğun hücre konsantrasyonuna ulaşılmaktadır. $\mathrm{Bu}$ aşama mikroalg türüne bağlı olarak farklı sürelerde görülebilmektedir. Takip eden süreçte hücre büyümesinin yavaşladığı ancak devam ettiği üçüncü evre gelmektedir. Hücre konsantrasyonundaki artış halen sürmektedir, ancak önceki aşamada olduğu kadar yüksek değildir. Ortamda maksimum hücre miktarına ulaşıldığ $\breve{1}_{1}$ ve optimum koşullardan uzaklaşılmaya başlandığında hücreler "durgun" 
evreye girmektedir. $\mathrm{Bu}$ evrede ortamdaki besin konsantrasyonu azalmış, hücreler arası rekabet artmış, yoğun mikroalg içeriğgi 1 şık iletimini engellemiş ve metabolik faaliyetler azalmıştır. Hücre ölümlerinin yanında çoğalmalar da devam etmektedir. Ayrıca, toplam hücre sayısında değişiklik olmaz ise hücreler daha çok sekonder metabolit üretimi yönüne ilerlemektedirler. Son aşama ise "ölüm” evresidir. Hücrelerin hızla öldüğü ve büyümenin neredeyse hiç olmadığı bu aşamaya gelindiğinde üretim sonlandırılmaktadır. Pek çok biyolojik proseste olduğu gibi mikroalgal biyokütle üretiminde de genel olarak görülen hücre büyüme profili bu şekildedir (Price ve Farag 2013; Lee vd. 2015).

Hücre büyümesi, ürün üretimi ve bunlar üzerine etki eden parametreler farklı modellerle ifade edilmektedir.

\section{Substrata Bağlı Modelleme}

Her organizmada olduğu gibi mikroalglerde de büyüme profilini etkileyen temel etmenlerden biri substrat konsantrasyonudur. Farklı mikroalg türleri için optimize edilen besin ortamlarında azot ve fosfat temel bileşenler olmak üzere bunlara ek olarak çeşitli iz elementler bulunmaktadır. Ayrıca hücrelerin gelişiminde en önemli faktör karbon kaynağıdır. Substrata bağlı olarak geliştirilen modellerden en yaygını Monod denkliğidir.

$$
\mu=\frac{\mu_{\max } \cdot C_{s}}{K_{S}+C_{s}}
$$

$\mu$, spesifik büyüme hızı (gün $\left.{ }^{-1}, \mathrm{sa}^{-1}\right) ; C_{s}$, substrat konsantrasyonu $(\mathrm{mg} / \mathrm{L}) ; \mu_{\max }$, maksimum spesifik büyüme hızı (gün $\left.{ }^{-1}, \mathrm{sa}^{-1}\right) ; K_{s}$, Monod doygunluk sabiti (mg/L).

$\mathrm{Bu}$ model, kültür ortamındaki besin bileşenlerinin tek başına büyüme üzerine etkilerini incelemekte olup, besin konsantrasyonunun düşük olduğu koşullar için kullanılmaktadır. Basit yapısı ve düşük besin konsantrasyonlarında doğru sonuçlar vermesi nedeniyle kullanımı yaygınlaşmıştır. Ancak yüksek substrat konsantrasyonlarında gerçekleşen inhibisyonun etkisini bu modelle görmek mümkün değildir. Bu sorunu önlemek için Monod eşitliğinin modifiye edilmesiyle oluşturulan modeller kullanılmaktadır. Bu amaçla belirlenen modellerden biri Haldane tarafindan oluşturulmuştur (Zhang vd. 1999; Lee vd. 2015; Sachdeva vd. 2016).

$$
\mu=\frac{\mu_{\max } \cdot C_{s}}{K_{S}+C_{s}+\frac{C_{s}^{2}}{K_{i}}}
$$

$K_{i}$, inhibisyon sabiti.

Eşitlik (1) ve (2) dışında substrat varlığı, yokluğu, besin kitlığ ya da inhibisyon koşullarını göz önünde bulunduran çeşitli modeller ortaya konmuştur. Ancak bu modeller sadece bir substratın büyüme üzerine etkisini ifade ettiğinden, tek başına kullanımları güvenilir sonuçlar vermemektedir (Zhang vd. 1999; Mirzaie vd. 2016).

Hücrelerin gelişiminde ortamdaki substrat miktarından daha çok hücrelerin bu substratı kullanabilme potansiyelleri önemlidir. Bu noktada tek bir hücre içindeki maksimum besin miktarı olarak tanımlanan "hücre kota"s1 devreye girmektedir. Monod benzeri modellerden farkl olarak bu modellerde belirli bir bileşen için hücrenin kotası değerlendirilir ve böylece ortamdaki besin eksikliğinde hücre büyüme davranışlarının ilerleyişi de incelenebilmektedir. Ancak hücre içerisindeki besin miktarının belirlenmesi çok zor bir yöntem olduğundan bu modellerin daha basitleştirilmiş modifiye halleri geliştirilmiştir. Bunların başında yaygin olarak kullanılan "Droop Model"i gelmektedir (Eşitlik 3). 1968 yılında M. R. Droop tarafından ortaya konan bu model, hücre büyüme hızı ile hücre içi besin konsantrasyonu arasındaki ilişkinin matematiksel ifadesidir (Droop, 1968). Modelde büyüme hızı her bir hücrede depolanan ortalama besin miktarı ile bağlantılıdır. Mikroalgler için Droop modeli özellikle doğal ortamda besin eksikliğinin yüksek olması dolayısıyla hücrelerin davranışlarını incelemek için kullanılmıştır. Ayrıca gerçekleştirilen üretimlerde azot ve fosfat eksikliğinde meydana gelen değişimlerin ortaya konmasında bu model ile gerçekçi sonuçlar elde edilmektedir (Lemesle ve Mailleret 2008; Packer 2014; Sachdeva vd. 2016).

$$
\mu=\mu_{\max }^{l}\left(1-\frac{Q_{\min }}{Q}\right)
$$

$\mu_{\text {max }}^{l}$, varsayımsal maksimum spesifik büyüme hızı $\left(\mathrm{gün}^{-1}, \mathrm{sa}^{-1}\right) ; Q_{\min }$, minimum hücre içi besin kotası (g/g karbon); $Q$ anlık hücre içi besin kotası $(\mathrm{g} / \mathrm{g}$ karbon).

Mikroorganizmaların karmaşı yaşam döngülerini açıklamak için oluşturulan ve yaygın kullanılan bir diğer model "Lojistik" modeldir (Eşitlik 4). Lojistik model biyolojik proseslere kolaylıkla entegre edilebilmesi, substrat konsantrasyonundan bağımsız olması ve özellikle fotoototrofik canlılar için kullanıldığında doğru modeller oluşturması sebebiyle tercih edilmektedir. $\mathrm{Bu}$ modelde hücre üretimini belirleyen temel nokta ortamın maksimum taşıyabileceği mikroalg popülasyonudur (Yang vd. 2011; Surendhiran vd. 2015).

$$
\frac{d X}{d t}=\mu_{m} X\left(1-\frac{X}{X_{m}}\right)
$$

$d X / d t$, mikroalg büyüme hızi; $X$, ortamdaki mikroalg konsantrasyonu $(\mathrm{g} / \mathrm{L}) ; X_{m}$, ortamın taşıyabileceği maksimum mikroalg konsantrasyonu $(\mathrm{g} / \mathrm{L})$. 


\section{Ișığa Bağlı Modelleme}

Substrat kaynağı tüm canlılar için primer yaşam gereksinimlerinden biridir. Ancak kompleks canl1 metabolizmas1 sadece substrattan değil canlı türüne göre pek çok bileşenden etkilenmektedir. Fotoototrofik canlilar için bu bileşenlerden en önemlisi 1 ş1k yoğunluğudur. Iş1k yoğunluğuna göre hücreler farklı davranışlar göstermektedir (Şekil 2) (Bechet vd. 2013; Lee vd. 2015).

- Düşük 1ş1k yoğunluğunda; hücreler metabolik faaliyetlerini sürdürmek için gerekli enerjiyi üretemezler. Hücrenin fotosentetik aktivitesi düşüktür bu da besin miktarı yeterli olsa da yaşam döngüsünü zorlaştırır.

- Doygunluk noktasındaki ișık yoğunluğunda, hücrenin fotosentetik aktivitesi maksimuma ulaşmaktadır. $\mathrm{Bu}$ noktadan sonra artan 1şık yoğunluğu fotosentez hızını arttırmaz. Hücreler 1şığa doygun hale gelir ve metabolik aktiviteler en iyi düzeydedir.

- Yüksek 1şık yoğunluğunda, fotosentezde etkili olan proteinlerin deaktivasyonu nedeniyle fotosentez hızında düşüşgörülmektedir. Bu noktadan sonra 1şığıı inhibeedici etkisi söz konusudur ve bu da "fotoinhibisyon" olarak tanımlanmaktadır (Bechet vd. 2013; Bernard vd. 2015; Lee vd. 2015).

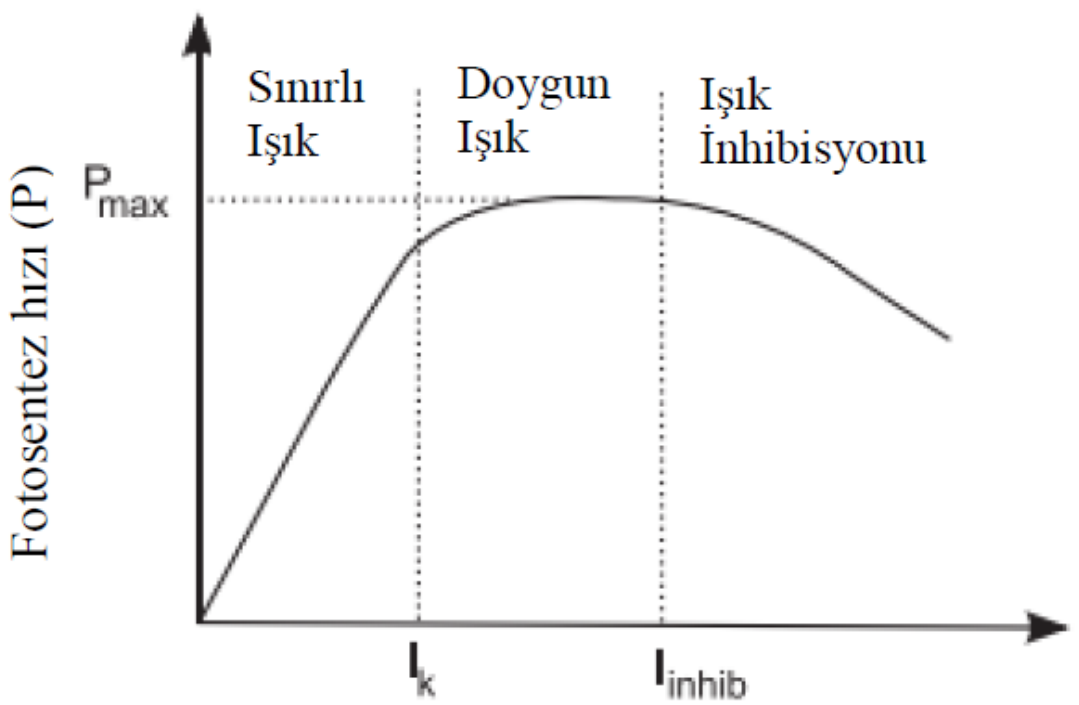

Işık Yoğunluğu (I)

Şekil 2. Işı̆̆ın fotosentez hızı üzerine etkisi (Bechet vd. 2013).

Figure 2. Effect of light intensity on photosynthesis rate

Işığa bağlı mikroalg modellemelerinde yapılması gereken ilk aşama üretim için ortalama 1 şık yoğunluğunun hesaplanmasıdır. Bunun için farklı yöntemler mevcut olmakla birlikte yaygın olarak Beer-Lambert yasası kullanılır (Mirzaie vd. 2016).

$$
I_{i}=I_{0}+e^{-\varepsilon \cdot X \cdot d}
$$

$I_{i}$, yerel 1şık yoğunluğu ( $\mu \mathrm{mol}$ foton $\left./ \mathrm{m}^{2} . \mathrm{s}\right) ; I_{0}$, reaktör yüzeyindeki 1 şı yoğunluğu $\left(\mu \mathrm{mol}\right.$ foton $\left./ \mathrm{m}^{2} . \mathrm{s}\right) ; \varepsilon$, molar absorpsiyon katsayısı (L/g.cm); $X$, biyokütle konsantrasyonu $(\mathrm{g} / \mathrm{L}) ; d$, 1şı yolu uzunluğu $(\mathrm{cm})$.

Ortalama 1şı yoğunluğu belirlendikten sonra hücre büyümesinin 1şığa bağlı değişimini gösteren model kullanılmaktadır. Yaygın olarak rastlanan modellerden biri Monod-benzeri modeldir (Perez vd. 2008; Bechet vd. 2013; Mirzaie vd. 2016).

$$
\mu=\frac{\mu_{\max } \cdot I}{I+K_{I}}
$$

$I$, kültürün içindeki ortalama 1şık yoğunluğu; $K_{I}$, 1ş1k doygunluk sabiti
$\mathrm{Bu}$ model Monod eşitliğinden farklı olarak substrat konsantrasyonu yerine 1 şık yoğunluğunun etkisini incelemekte ve spesifike olarak 1 şı yoğunluğunun doygunluk noktasından düşük olduğu üretimlerin modellenmesinde tercih edilmektedir.

Işı yoğunluğunun etkisini gösteren Monodbenzeri model dışında deneysel olarak ortaya konmuş çok sayıda model mevcuttur. Yaygın olarak kullanılan diğer modeller Eşitlik (7), (8) ve (9)'da verilmiştir (Chalker 1980; Yuan vd. 2014; Lee vd. 2015).

$$
\begin{aligned}
& \mu=\mu_{\max } \tanh \frac{I}{K_{I}} \\
& \mu=\mu_{\max }\left(1-e^{-I / K_{I}}\right) \\
& \mu=\mu_{\max } \frac{I}{\left(K_{I}^{m}+I^{m}\right)^{1 / m}}
\end{aligned}
$$

$m$; şekil faktörü 
Laboratuvar ortamında gerçekleştirilen, yoğun mikroalg kültürü içermeyen üretimlerde 1şı̆̆ın etkisinin görülmesi için Monod benzeri ya da hiperbolik tanjant modeli kullanılabilmektedir. Ancak çoğu mikroalgal biyoproses için düşük hücre konsantrasyonu yeterli olmamaktadır. Hücre konsantrasyonu arttıkça 1şı̆̆ın penetrasyonu, homojen dağılımı gibi özellikleri de değişmektedir (Grima vd. 1994; Lee vd. 2015; Huesemann vd. 2016). Bu tip kültürlerde 1 şı etkisini incelemek için yaygın olarak kullanılan model;

$$
\mu=\mu_{\max } \frac{I_{a v}^{n}}{I_{k}^{n}+I_{a v}^{n}}
$$

$I_{k} ;$ Mikroalgin 1şı̆̆a karşı afinitesi $\left(\mu \mathrm{E} / \mathrm{m}^{2} . \mathrm{s}\right)$, $I_{a v}$; Kültürdeki ortalama 1 şı yoğunluğu $\left(\mu \mathrm{E} / \mathrm{m}^{2} . \mathrm{s}\right)$, $n$; Üssel katsayı

Modelde ifade edilen ortalama 1şık yoğunluğu her üretim için değişmekte olup 1şı1k yolunun uzunluğu, hücre konsantrasyonu ve yüzeydeki $1 s ̧ 1 k$ yoğunluğu dikkate alınarak Eşitlik (11)'e göre hesaplanmaktadır (Grima vd. 1994; Lee vd. 2015; Huesemann vd. 2016).

$$
I_{a v}=\frac{I}{K_{a} p X}\left[1-e^{-K_{a} p X}\right]
$$

$K_{a}$, sönümleme sabiti $\left(\mathrm{kg} / \mathrm{m}^{3}\right) ; p$, fotobiyoreaktör içindeki 1 şı yolu uzunluğu $(\mathrm{m}) ; \quad X$, hücre konsantrasyonu $\left(\mathrm{kg} / \mathrm{m}^{3}\right)$

Önceki modellerin tamaminda hücrelerin ortalama 1şık yoğunluğunda üretildiği ve fotosentetik aktivitelerinin istenen oranda gerçekleştiği durumların nicel ifadesi üzerinde durulmuştur. Ancak kontrol altına alınamayan özellikle dış ortam koşullarında gerçekleştirilen üretimlerde 1 şık miktarı istenen düzeyden çok yüksek olabilir. $\mathrm{Bu}$ istenmeyen durumlarda 1 şı inhibisyonu sonucu fotosentez hızı düşmektedir. $\mathrm{Bu}$ üretimlerin hem sınırlı hem de yüksek ışık koşullarını değerlendirmek için kombine model geliştirilmesi avantajlı bir durumdur. Hem düşük ışığın sınırlandırıcı etkisini hem de yüksek 1şı̆̆ı̆ inhibe edici etkisini birlikte gösteren karmaşık modeller bulunmaktadır (Steele 1962; Lee vd. 2015). Bunların içinde en yaygın kullanılanı Steele (1962) tarafindan ortaya konan aşağıdaki modeldir;

$$
\mu=\mu_{\max } \frac{I}{I_{o p t}} \mathrm{e}^{\left(1-\frac{I}{I_{o p t}}\right)}
$$

$\mathrm{Bu}$ eşitlikte $\frac{I}{I_{o p t}}$ ifadesi düşük 1 ş1k konsantrasyonlarında hücrelerdeki fotosentetik aktivitenin ve büyümenin sınırlanmasını ifade ederken, $e^{\left(1-\frac{I}{I_{\text {opt }}}\right)}$ değeri yüksek 1 şı şiddetinde azalan fotosentetik aktiviteyi göstermektedir.

\section{Sıcaklığa Bağlı Modelleme}

Her biyolojik proseste olduğu gibi mikroalgal biyokütle üretiminde de sicaklık optimizasyonu önemli parametrelerden biridir. Hücredeki metabolik faaliyetlerden sorumlu enzimler ve proteinlerin aktivitesi açısından optimum sıcaklık koşulları sağlanmalıdır. Sıcaklığın hücre büyümesine etkisinin incelendiği en basit modellerden biri Arrhenius benzeri sıcaklık eşitliğidir (Perez vd. 2008).

$$
\mu=A \exp \left(-\frac{E_{a}}{R T}\right)-B \exp \left(-\frac{E_{b}}{R T}\right)
$$

$A$ ve $B$; frekans faktörü $\left(\mathrm{sa}^{-1}\right), R$; gaz sabiti $(\mathrm{kcal} / \mathrm{mol})$, $T$; üretim sicaklığı $(\mathrm{K}), E_{a}$; hücre büyümesi için gerekli aktivasyon enerjisi, $E_{b}$; hücresel degredasyon için gerekli aktivasyon enerjisi.

Sadece sıcaklığın hücre büyümesi ve fotosentetik aktivite üzerine etkisinin incelenmesiyle bir model oluşturulsa da diğer faktörlerin de göz önünde bulundurulması daha doğru sonuç vermektedir. Işık ve sıcaklığın büyüme ve fotosenteze birlikte etkilerinin incelenmesi amaciyla Monod ve Arrhenius eşitlikleri birlikte kullanılarak Eşitlik (14) geliştirilmiştir (Goldman ve Carpenter 1974; Carcano 2010; Bechet vd. 2013).

$$
\mu=\mu_{\text {max }} \exp \left(-\frac{E_{a}}{k T}\right) \cdot \frac{I_{a v}}{K+I_{a v}}
$$

$K$, 1şı sabiti $\left(\mu \mathrm{mol} / \mathrm{m}^{2} \mathrm{~s}\right) ; k$, Boltzmann sabiti $(\mathrm{J} / \mathrm{kg})$

Arrhenius benzeri modelin farklı mikroalg türleri ve üretimler için geliştirilmiş çok sayıda modeli mevcuttur. Ancak bu modeller yalnızca metabolik aktiviteler için optimum sicaklık değerlerinin korunduğu prosesler için uygulanmaktadır. Ortam sıcaklığı yükseldikçe enzimlerin yapısında denatürasyon meydana gelmekte ve inaktif hale geçmektedirler. $\mathrm{Bu}$ sorunu önlemek için enzim degredasyonunu da içeren benzer modeller geliş̧irilmektedir (Eşitlik 15) (Bechet vd. 2013).

$$
\mu(I)=\mu_{m, 0}(I) \frac{\exp \left(-\frac{E_{a}}{R T}\right)}{1+\operatorname{Kexp}\left(-\frac{E_{a}^{l}}{k T}\right)}
$$

Bu modelde Eşitlik (14)'den farklı olarak yüksek sicaklıkta meydana gelen enzim denatürasyonunu

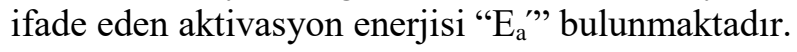

Mikroalgin büyümesinde etkili olan faktörlerin bireysel olarak büyüme ve ürün oluşumu üzerine etkisinin incelenmesi kullanışlı bir yöntemdir, ancak bu faktörlerin birbirleriyle etkileşimleri de üreme kinetiğinde önemlidir. Özellikle açık sistemlerde gerçekleştirilen üretimlerde prosesin kontrolü zor olduğundan değişen parametrelerin üretim üzerindeki etkisi daha büyüktür. $\mathrm{Bu}$ yüzden birkaç faktörün etkisinin birlikte gösterildiği çoklu kombine modeller geliştirilmiştir. Bu modellerde azot, fosfat, $\mathrm{CO}_{2}$, 1şık 
yoğunluğu ve sıcaklık parametrelerinden birkaçının etkisi birlikte incelenerek daha karmaşı modeller oluşturulmuştur. Bu modellerden bazıları Tablo 1'de gösterilmektedir.

Tablo 1. Mikroalgal hücre büyümesinde çoklu faktör etkisini gösteren modeller

Table 1. Models showing effects of multi level factors on the microalgal cell growth.

\begin{tabular}{|c|c|c|c|}
\hline Mikroalgal büyüme modelleri & Parametreler & $\begin{array}{l}\text { Denklem } \\
\text { Numarası }\end{array}$ & Referans \\
\hline$\mu=\mu_{m a x, \min }^{\prime}\left(1-\frac{Q_{\min , N}}{Q_{N}}, 1-\frac{Q_{\min , P}}{Q_{P}}\right)$ & Azot, Fosfat & (16) & $\begin{array}{l}\text { Klausmeier vd. } \\
2004\end{array}$ \\
\hline$\mu=\mu_{\max , \min }^{\prime}\left(\frac{1-\frac{Q_{\min , N}}{Q_{N}}}{1-\frac{Q_{\min , N}}{Q_{\max , N}}}, \frac{1-\frac{Q_{\min , P}}{Q_{P}}}{1-\frac{Q_{\min , P}}{Q_{\max , P}}}\right)$ & Azot, Fosfat & (17) & $\begin{array}{l}\text { Bougaran vd. } \\
2010\end{array}$ \\
\hline$\mu=\mu_{\max , \min }\left(\frac{S_{P}}{K_{S, P}+S_{P}}, \frac{S_{C O_{2}}}{K_{S, C O_{2}}+S_{C O_{2}}}\right)$ & $\begin{array}{l}\text { Karbondioksit, } \\
\text { Fosfat }\end{array}$ & (18) & $\begin{array}{l}\text { Spijkerman vd. } \\
2011\end{array}$ \\
\hline$\mu=\mu_{\max , \min }^{\prime}\left[1-\left(\frac{Q_{N, \min }}{Q_{N}}\right)^{4}, 1-\left(\frac{Q_{P, \min }}{Q_{p}}\right)^{4}\right] \cdot f\left(I_{a v}\right)$ & Azot, Fosfat, Işık & (19) & Lee vd. 2015 \\
\hline$\mu=\mu_{m a x} \cdot Q^{T-T_{r e f}}\left(\frac{I}{K_{I}+I}\right)\left(\frac{S_{P}}{K_{S, P}+S_{P}}\right)\left(\frac{S_{N}}{K_{S, N}+S_{N}}\right)$ & $\begin{array}{l}\text { Azot, Fosfat, } \\
\text { Sicaklık, Işık }\end{array}$ & (20) & Haario vd. 2009 \\
\hline$\mu=\mu_{\max } .1 .06^{T-20}\left(\frac{I_{a v}^{m}}{K_{I}^{m}+I_{a v}^{m}}\right)\left(\frac{S_{C O 2}}{K_{S, C O 2}+S_{C O 2}+\frac{S_{C O 2}^{2}}{K_{I, C O 2}}}\right)$ & $\mathrm{CO}_{2}, 1$ şık, sıcaklık & $(21)$ & $\begin{array}{l}\text { Pegallapati ve } \\
\text { Nirmalakhanda } \\
\quad 2012\end{array}$ \\
\hline $\begin{array}{l}\mu=\mu_{m} \frac{S_{N}}{S_{N}+K_{N A}}\left(\frac{S_{C O 2}}{S_{C O 2}+K_{C O 2}}\right) f(l) \\
f(l)=\frac{I_{a v}}{I_{s}} \exp \left(1-\frac{I_{a v}}{K_{s, l}}\right)\end{array}$ & $\mathrm{CO}_{2}$, 1şık, azot & $(22)$ & $\begin{array}{l}\text { Jalalizadeh } \\
2012\end{array}$ \\
\hline
\end{tabular}

$\mu_{\text {max,min: }}^{\prime}$ Sınırlayıcı besin için sonsuz hücre kotasında varsayımsal maksimum büyüme hızı (gün $\left.{ }^{-1}, \mathrm{sa}^{-1}\right), Q_{\text {min }}$ : Hücre canlılığ için gerekli minimum besin kotası (g/g karbon), $Q$ : Hücrenin besin kotası (g/g karbon), $O_{\max }$ : Hücre canlılı̆̆ için gerekli maksimum besin kotası (g/g karbon), $N$ : nitrogen, $P$ : phosphorus, $S$ : Besin konsantrasyonu (mg/L), $K_{s}$ : Monod yarı doygunluk sabiti $(\mathrm{mg} / \mathrm{L}), f\left(I_{a v}\right)$ : Ortalama $1 s ̧ 1 \mathrm{k}$ yoğunluğu fonksiyonu, $T$ : sıcaklık $\left({ }^{\circ} \mathrm{C}\right), T_{r e f}$ : Referans sıcaklığ $1\left(20^{\circ} \mathrm{C}\right), K_{I}$ : Işı1k doygunluk sabiti $\left(\mu \mathrm{mol} / \mathrm{m}^{2} \mathrm{~s}\right), K_{N A}$ : Sabit, $K_{\mathrm{CO} 2}: \mathrm{CO}_{2}$ Doygunluk sabiti.

\section{Mikroalgal Ürün Üretiminin Kinetik Modellenmesi

$$
\frac{d p}{d t}=\alpha \frac{d x}{d t}+\beta x
$$

Açık ve kapalı olmak üzere çeşitli sistemlerde yetiştirilen mikroalglerde hedef ürün endüstriyel alana göre değişiklik göstermektedir. Yağ içeriğinin arttırılarak biyoyakıt olarak kullanımı, primer ve sekonder metabolit üretimi ile katma değeri yüksek ürünlerin eldesi, biyokütle miktarının artırımı ile yem endüstrisinde kullanımı gibi çalışmalar yaygın olarak karşılaşılan proses çıktılarındandır. İstenen amaç doğrultusunda mikroalgal biyokütleyi arttırmak kadar ürün üretimini de optimize etmek önemlidir. $\mathrm{Bu}$ nedenle hücre büyümesinin yanı sıra üretimin modellemesi de diğer prosesler ve mikroalgler için yol gösterici olmaktadır. Mikrobiyal prosesler için ürün üretiminin ifadesi için yaygın olarak kullanılan model "Luedeking-Piret" modelidir. Bu modelde ürün oluşumu biyokütle konsantrasyonu ve spesifik büyüme hızı ile doğru orantılıdır. $\frac{d_{p}}{d_{t}}$, ürün oluşum hızı; $\frac{d_{x}}{d_{t}}$, mikroalg büyüme hızı; $\alpha$, ürün oluşum katsayısı; $\beta$, hücre büyümesinden bağımsız ürün oluşum katsayısı

$\mathrm{Bu}$ model hem kolay kullanımı hem de ürün çeşidine göre entegre edilebilirliği açısından yaygın kullanılmaktadır.

Mikroorganizmalarda üretilen ürünler hücre büyümesiyle ilişkili olması açısından 3 gruba ayrılmaktadırlar. İlk grupta, ürün üretimi hücre büyümesiyle doğrudan ilişkilidir. Bu gruptaki ürünler genel olarak hücre büyümesi için hayati önem taşıyan primer metabolitler olarak adlandırılmaktadır. İkinci grupta ise hücre büyümesiyle kısmen ilişkili olan ürünler bulunmaktadır. Hücrede büyüme görülmese de ürün üretilmeye devam eder, ancak maksimum ürün miktarı ve ürün kalitesi hücre üremesinin en 
yüksek olduğu dönemde görülmektedir. Son grupta ise hücre büyümesinden tamamen bağımsız olarak üretilen ürünler görülmektedir. Genel olarak hücrenin strese girdiği koşullarda bir nevi savunma mekanizması oluşturmak için ürettiği ürünleri kapsayan bu grupta sekonder metabolitler mevcuttur. Luedeking-Piret modeli sahip olduğu katsayılar sayesinde bu 3 gruptan her biri için uyarlanabilir (Yang vd. 2011; Ronda vd. 2012; Vinayagam vd. 2014; Surendhiran vd. 2015).

- $\alpha=0$ ve $\beta \neq 0 \rightarrow$ Ürün oluşumu hücre büyümesinden bağımsızdır;

- $\alpha \neq 0$ ve $\beta \neq 0 \rightarrow$ Ürün oluşumu hücre büyümesiyle kısmen ilişkilidir;

- $\alpha \neq 0$ ve $\beta=0 \rightarrow$ Ürün oluşumu doğrudan hücre büyümesiyle bağlantılıdır.

\section{Tartışma ve Sonuç}

Mikroalg hücrelerinin büyüme kinetiği ve ürün üretimi, substrat konsantrasyonu, 1şık yoğunluğu, sıcaklık, gaz konsantrasyonu gibi çeşitli faktörlerden etkilenen karmaşık bir prosestir. Literatürde bu faktörlerin etkisinin incelenmesi amacıyla çok sayıda kinetik modele rastlamak mümkündür. Geliştirilen modellerden sadece bir faktörün etkisinin incelendiği eşitlikler uygulama açısından kolaydır ancak ortaya çıkan sonuçlar değerlendirildiğinde daha doğru çıktılar için modifikasyon gereksinimi doğmaktadır. $\mathrm{Bu}$ nedenle, çoklu faktörlerin etkisinin incelendiği daha karmaşık ancak daha tutarlı sonuçlar veren modeller geliştirilmiştir. Gelecek çalışmalar için daha etkili modellerin ortaya konması mikroalg üretimlerinin daha verimli olmasını ve olası sorunların önlenmesini sağlayacaktır. Ayrıca mikroalg türleri doğada monokültür halinde değil diğer organizmalar ile birlikte yaşamaktadır. $\mathrm{Bu}$ yüzden, mikroalg davranışlarının daha doğru incelenmesi adına habitattaki diğer türlerin de etkisinin değerlendirildiği modeller üzerine çalışmalara yoğunlaşılmalıdır.

\section{Teșekkür}

Bu makale, ES1408 COST aksiyonu kapsamında olup Türkiye Bilimsel ve Teknolojik Araştırma Kurumu (TUBITAK) 115M014 proje kapsamında finansal olarak desteklenmiştir.

\section{Kaynaklar}

Bechet Q, Shilton A, Guieysse B. 2013. Modeling the effects of light and temperature on algae growth: State of the art and critical assessment for productivity prediction during outdoor cultivation. Biotechnol Adv. 31(8):1648-1663.

doi: 10.1016/j.biotechadv.2013.08.014
Bernard O, Mairet F, Chachuat B. 2015. Modelling of microalgae culture systems with applications to control and optimization. Adv Biochem Eng Biotechnol. 153:59-87. doi: 10.1007/10_2014_287

Bougaran G, Bernard O, Sciandra A. 2010. Modeling continuous cultures of microalgae colimited by nitrogen and phosphorus. J Theor Biol. 265(3):443454.

doi: 10.1016/j.jtbi.2010.04.018

Carcano S. 2010. A model for cell growth in batch bioreactors [Master's Thesis]. Politecnico Di Milano. $128 \mathrm{p}$.

Chalker BE. 1980. Modeling light saturation curves for photosynthesis: An exponential function. $\mathrm{J}$ Theor Biol. 84(2):205-215. doi: 10.1016/S0022-5193(80)80004-X

Droop M. 1968. Vitamin B12 and marine ecology. IV. The kinetics of uptake, growth and inhibition in Monochrysis Lutheri. J Mar Biol Assoc U.K. 48(3):689-733. doi: $10.1017 / \mathrm{S} 0025315400019238$

Goldman JC, Carpenter EJ. 1974. A kinetic approach to the effect of temperature on algal growth. Limnol Oceanogr. 19(5):756-766. doi: 10.4319/lo.1974.19.5.0756

Grima EM, Camacho FG, Perez JAS, Sevilla JMF, Fernandez FGA, Gomez AC. 1994. A mathematical model of microalgal growth in light-limited chemostat culture. J Chem Technol Biot. 61(2):167-173. doi: $10.1002 /$ jctb. 280610212

Haario H, Kalachev L, Laine M. 2009. Reduced models of algae growth. Bull Math Biol. 71(7):1626-1648. doi: 10.1007/s11538-009-9417-7

Huesemann M, Crowe B, Waller P, Chavis A, Hobbs S, Edmundson S, Wigmosta M. 2016. A validated model to predict microalgae growth in outdoor pond cultures subjected to fluctuating light intensities and water temperatures. Algal Res. 13:195-206. doi: 10.1016/j.algal.2015.11.008

Jalalizadeh M. 2012. Development of an integrated process model for algae growth in a photobioreactor [Master's Thesis]. University of South Florida. 76 p.

James SC, Boriah V. 2010. Modeling algae growth in an open-channel raceway. J Comput Biol. 17(7):895-906. doi: 10.1089/cmb.2009.0078

Klausmeier CA, Litchman E, Levin SA. 2004. Phytoplankton growth and stoichiometry under multiple nutrient limitation. Limnol Oceanogr. 49(4part2):1463-1470. doi: 10.4319/1o.2004.49.4_part_2.1463

Koutinas M, Kiparissides A, Pistikopoulos EN, Mantalaris A. 2012. Bioprocess systems engineering: Transferring traditional process engineering principles to industrial biotechnology. Comput Struct Biotech. 3(4):e201210022. doi: $10.5936 / \mathrm{csbj} .201210022$

Lee E, Jalalizadeh M, Zhang Q. 2015. Growth kinetic models for microalgae cultivation: A review. Algal Res. 12:497-512. doi: 10.1016/j.algal.2015.10.004 
Lemesle V, Mailleret L. 2008. A mechanistic investigation of the algae growth "Droop" model. Acta Biotheor. 56:87-102. doi: 10.1007/s10441-008-9031-3

Mirzaie MAM, Kalbasi M, Ghobadian B, Mousavi SM. 2016. Kinetic modeling of mixotrophic growth of Chlorella vulgaris as a new feedstock for biolubricant. J Appl Phycol. 28:2707-2717. doi: 10.1007/s10811-016-0841-4

Packer A. 2014. Cell quota based population models and their applications $[\mathrm{PhD}$ Thesis]. Arizona State University. $116 \mathrm{p}$.

Pegallapati AK, Nirmalakhandan N. 2012. Modeling algal growth in bubble columns under sparging with $\mathrm{CO}_{2}$ enriched air. Bioresour Technol. 124:137-145. doi: 10.1016/j.biortech.2012.08.026

Perez EB, Pina IC, Rodriguez LP. 2008. Kinetic model for growth of Phaeodactylum tricornutum in intensive culture photobioreactor. Biochem Eng J. 40(3):520525 .

doi: 10.1016/j.bej.2008.02.007

Price K, Farag IH. 2013. Resources conservation in microalgae biodiesel production. Int J Eng Tech Res. 1(8):49-56.

Ronda SR, Bokka CS, Ketineni C, Rijal B, Allu PR. 2012. Aeration effect on Spirulina platensis growth and Glinolenic acid production. Braz J Microbiol. 43(1):12-20. doi: 10.1590/S1517-83822012000100002

Sachdeva N, Kumar GD, Gupta RP, Mathur AS, Manikandan B, Basu B, Tuli DK. 2016. Kinetic modeling of growth and lipid body induction in Chlorella pyrenoidosa under heterotrophic conditions. Bioresour Technol. 218:934-943. doi: 10.1016/j.biortech.2016.07.063
Spijkerman E, de Castro F, Gaedke U. 2011. Independent colimitation for carbon dioxide and inorganic phosphorus. PIOs ONE. 6(12):e28219. doi: 10.1371/journal.pone.0028219

Steele JH. 1962. Environmental control of photosynthesis in the sea. Limnol Ocenaogr. 7(2): $137-150$. doi: 10.4319/1o.1962.7.2.0137

Surendhiran D, Vijay M, Sivaprakash B, Sirajunnisa A. 2015. Kinetic modeling of microalgal growth and lipid synthesis for biodiesel production. 3 Biotech. 5(5):663-669.

doi: 10.1007/s13205-014-0264-3

Vinayagam R, Vytla RM, Chandrasekaran M. 2014. Development of a simple kinetic model and parameter estimation for biomass and nattokinase production by Bacillus subtilis 1a752. Austin J Biotech Bioeng. 2(1):1-5.

Yang JS, Rasa E, Tantayotai P, Scow KM, Yuan HL, Hristova KR. 2011. Mathematical model of Chlorella minutissima UTEX2341 growth and lipid production under photoheterotrophic fermentation conditions. Bioresour Technol. 102(3):3077-3082. doi: 10.1016/j.biortech.2010.10.049

Yuan S, Zhou X, Chen R, Song B. 2014. Study on modelling microalgae growth in nitrogen-limited culture system for estimating biomass productivity. Renew Sustain Energy Rev. 34:525-535. doi: 10.1016/j.rser.2014.03.032

Zhang XW, Gong X-D, Chen F. 1999. Kinetic models for astaxanthin production by high cell density mixotrophic culture of the microalga Haematococcus pluvialis. J Ind Microbiol Biot. 23(1):691-696. doi: 10.1038/sj.jim.2900685 